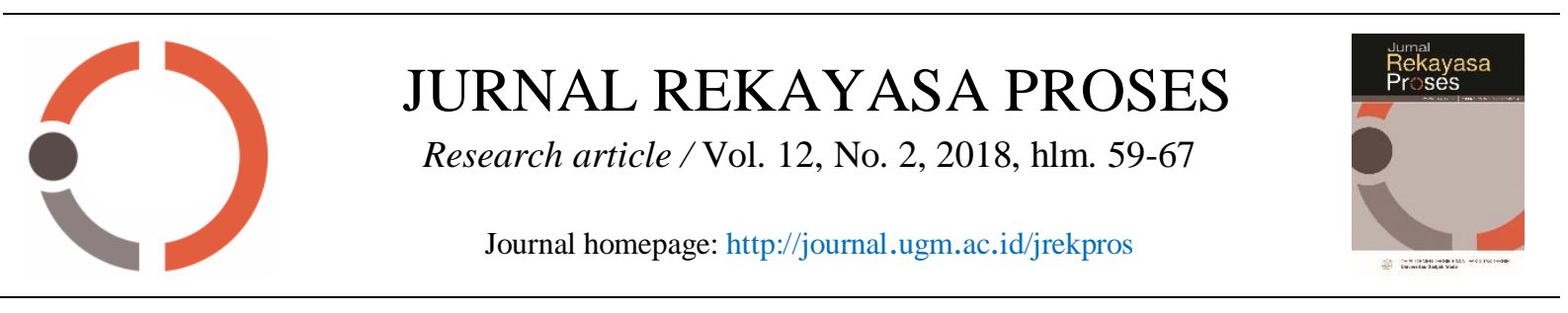

\title{
Benefisiasi Bijih Emas dan Perak Kadar Rendah Menggunakan Palong dan Metode Flotasi
}

\author{
Widi Astuti*, Kusno Isnugroho, Fika Rofiek Mufakhir, Ulin Herlina, Isti Nurjanah \\ Balai Penelitian Teknologi Mineral - LIPI \\ Jl. Ir. Sutami Km. 15 Tanjungbintang, Lampung Selatan, Lampung \\ *Alamat korespondensi:widi.mineral@gmail.com,widi004@lipi.go.id
}

(Submisi 18 Mei 2018; Revisi 2 Juli 2018; Penerimaan 20 Juli 2018)

\section{A B S T R A C T}

Beneficiation of low-grade gold and silver ores were investigated by gravity concentration flotation methods. The ores were obtained from Way Kanan Region and Mount Burhan in Province of Lampung. In this study, gravity concentration in sluice box and flotation were performed in sequence. Effect of particle size was investigated in gravity concentration by sluice box. Furthermore, effect of various parameters in flotation operation such as concentration of collector, ore particle size, and processing time were studied. Gravity concentration in sluice box indicated that the highest recovery of gold and silver were $76.52 \%$ and $94.83 \%$, respectively when using ore particle size of $100+150$ mesh. Flotation experiments showed that the maximum recoveries of gold and silver obtained were $98.33 \%$ and $86.42 \%$. The conditions to obtain maximum recovery in this study were $-100+150$ mesh of ores particle size, $25 \mathrm{~mL} / \mathrm{kg}$ concentration of collector, and 25 minutes of processing time.

Keywords: beneficiation; flotation, gold ore; silver ore; sluice box.

\section{A B S T R A K}

Benefisiasi bijih emas dan perak kadar rendah menggunakan konsentrasi gravitasi dengan palong dan menggunakan flotasi telah dilakukan. Bijih emas dan perak yang digunakan berasal dari daerah Way Kanan dan Gunung Burhan di Provinsi Lampung. Pada penelitian ini, konsentrasi gravitasi dengan palong dilakukan terlebih dahulu sebelum dilakukan benefisiasi menggunakan flotasi. Pengaruh ukuran partikel dipelajari pada konsentrasi gravitasi dengan palong. Sedangkan pengaruh beberapa variabel seperti konsentrasikolektor, ukuran partikel, dan waktu flotasi dipelajari dalam proses benefisiasi menggunakan flotasi. Pada konsentrasi gravitasi dengan palong, hasil percobaan menunjukkan bahwa persen recovery emas dan perak tertinggi secara berturut-turut adalah 76,52\% dan 94,83\% ketika digunakan ukuran partikel -100+150 mesh. Pada proses flotasi, hasil percobaan menunjukkan bahwa persen recoveryemas dan perak maksimum yang diperoleh adalah 98,33\% dan $86,42 \%$ ketika digunakan ukuran partikel $-100+150$ mesh, konsentrasi kolektor $25 \mathrm{~mL} / \mathrm{kg}$ dan waktu flotasi 25 menit.

Kata kunci: benefisiasi; emas; flotasi; palong; perak

\section{Pendahuluan}

Emas $(\mathrm{Au})$ dan perak $(\mathrm{Ag})$ merupakan salah satu jenis mineral yang memiliki banyak manfaat.
Jenis mineral ini dapat digunakan sebagai bahan konduktor pengantar panas di beberapa jenis alat elektronik. Namun, kegunaan emas dan perak yang utama adalah sebagai bahan perhiasan dan 
mata uang. Indonesia merupakan salah satu negara yang memiliki banyak tambang emas dan perak yang tersebar mulai dari Pulau Sumatera, Pulau Jawa, Pulau Kalimantan, dan Papua. Sumber daya dan cadangan mas di Indonesia cukup besar. Menurut laporan dari Kementerian Energi dan Sumber Daya Mineral (ESDM) tahun 2017 tercatat sumber daya emas terukur sebesar 1.755 ton dan sumberdaya terbukti sebesar 2.357 ton. Ini dapat dilihat dari jumlah tersebarnya daerah tambang-tambang emas di Indonesia dengan 285 titik lokasi (ESDM, 2017). Provinsi Lampung di Pulau Sumatera merupakan salah satu daerah yang memiliki cadangan emas dan perak yang tersebar di 11 wilayah, namun baru beberapa titik saja yang bisa diprediksi potensinya. Menurut data Dinas Pertambangan Provinsi Lampung tahun 2012, perkiraan jumlah bijih emas yang diketahui di Pekon Cukuh Balak dan Pekon Putih Doh Kabupaten Tanggamus masing-masing sebesar 415.677 ton dan 190.250 ton, Desa Babakan Loa Kabupaten Pesawaran sebesar 218.346 ton dan Kampung Gistan Kabupaten Waykanan sebesar 870.309 ton (ESDM, 2017)

Teknologi proses pengolahan bijih emas yang umum digunakan di industri pengolahan emas adalah sianidasi dan amalgamasi. Metode amalgamasi ini cukup mudah dilakukan karena lebih praktis tetapi limbah yang dihasilkan tidak ramah lingkungan. Di lain pihak, proses sianidasi lebih kompleks dan menimbulkan dampak negatif juga terhadap lingkungan. Kedua metode ini menjadi kurang menguntungkan jika digunakan untuk mengolah bijih emas dan perak dengan kadar rendah.Untuk itu diperlukan teknologi peningkatan kadar emas dan perak (benefisiasi bijih) sebagai upaya untuk mempersiapkan konsentrat emas dan perak yang siap diproses lebih lanjut yang biasanya disebut proses konsentrasi. Beberapa faktor yang menyebabkan konsentrasi bijih emas harus dilakukan sebelum dilanjutkan dengan proses lainnya seperti sianidasi, amalgamasi dan peleburan diantaranya adalah kadar rendah dan ukuran butir. Konsentrasi merupakan salah satu proses yang penting dalam suatu rangkaian pengolahan emas. Konsentrasi gaya berat (gravitasi) dan flotasi banyak digunakan dalam pengolahan emas (Wahyudi, 2004; Ferdana dkk., 2018; Prasetya dkk., 2018).

Alat utama yang banyak dipakai pada konsentrasi gravitasi adalah jig, meja goyang, palong (sluice box) dan spiral. Pada penelitian ini digunakan palong untuk pengonsentrasian bijih emas dan perak sehingga diperoleh konsentrat emas dan perak dengan kadar yang lebih tinggi dibandingkan kadar bijih sebelumnya. Konsentrasi dengan palong dilakukan sebelum dilakukan benefisiasi dengan metode flotasi agar proses flotasi berlangsung lebih efektif dan efisien serta mengurangi beban kerja reagen yang digunakan (Marsden \&House, 1999; Sudarsono, 2003;).

Prinsip kerja flotasi adalah memisahkan suatu mineral dari bijihnya dengan cara mengapungkan mineral tersebut sehingga terpisah dari mineralmineral lainnya yang tetap terdapat dalam suspensi. Proses ini dilakukan dalam suatu alat yang disebut sel flotasi. Supaya terjadi pemisahan, dalam sel flotasi harus diinjeksi udara membentuk gelembung-gelembung udara sebagai tempat menempelnya butiran mineral tertentu. Proses flotasi hanya dapat dilakukan untuk partikel berukuran relatif halus (Marsden \& House, 1999; Sudarsono, 2003).

Pada kegiatan ini dilakukan penelitian benefisiasi emas dan perak dengan bahan baku berasal dari Way Kanan dan Gunung Burhan di Provinsi Lampung menggunakan palong. Lalu dilanjutkan dengan metode flotasi sehingga diperoleh kondisi optimum proses benefisiasi emas dan perak dari tambang rakyat yang dapat diterapkan oleh industri kecil dan menengah. Kondisi optimum pengolahan bijih emas dan perak ini adalah kondisi yang menghasilkan konsentrat emas dan perak dengan kadar yang tinggi.

\section{Metode Penelitian}

\subsection{Bahan baku}

Bahan baku yang digunakan berupa bijih emas yang mengandung emas dan perak berasal dari daerah Lampung Selatan dan Way Kanan, Provinsi Lampung. Kandungan Au dan Ag dalam 
bahan baku dianalisis menggunakan analisis kimia basah. Tabel 1 menggambarkan kompoisi $\mathrm{Au}$ dan Ag dalam bahan baku bijih emas dari daerah Lampung Selatan dan Way Kanan.

Tabel 1. Kandungan Au dan Ag dalam sampel bahan baku

\begin{tabular}{ccc}
\hline \multirow{2}{*}{ Kandungan } & \multicolumn{2}{c}{ Sampel } \\
\cline { 2 - 3 } & A (Lampung Selatan) & $\mathrm{B}$ (Way Kanan) \\
\hline $\mathrm{Au}$ & $0,38 \mathrm{gr} /$ ton & $2,9 \mathrm{gr} / \mathrm{ton}$ \\
$\mathrm{Ag}$ & $13 \mathrm{gr} / \mathrm{ton}$ & $11 \mathrm{gr} / \mathrm{ton}$ \\
\hline
\end{tabular}

Sebelum dilakukan konsentrasi dalam palong dan flotasi, sampel bahan baku dihaluskan dan diayak terlebih dahulu untuk mendapatkan ukuran $-60+80$ mesh, $-80+100$ mesh, $-100+150$ mesh, $-150+200$ mesh, dan -200 mesh.

\subsection{Reagen flotasi}

Reagen flotasi yang digunakan adalah reagen teknis yang terdiri dari pine oil sebagai frother dan xylene sebagai kolektor.

\subsection{Proses benefisiasi}

Proses benefisiasi dilakukan dalam dua tahap yaitu proses konsentrasi dengan palong dan proses flotasi.

\subsubsection{Proses konsentrasi dengan palong}

Proses konsentrasi dilakukan dalam palong dengan kemiringan $5^{\circ}$. Media konsentrasi yang digunakan adalah air dengan debit air 7 liter/menit. Besaran sudut kemiringan mengacu pada standar (Walkin, 2009) dan debit air yang digunakan berdasarkan pada kondisi alat pompa yang tersedia. Proses konsentrasi memanfaatkan sifat densitas bijih, yang lebih ringan akan terbawa aliran air dan ditampung sebagai tailing, sedangkan yang berat akan tertinggal di palong dan diambil sebagai konsentrat. Konsentrat dan tailing yang diperoleh dari proses pencucian dikeringkan dan ditimbang serta dianalisis kadar $\mathrm{Au}$ dan Ag untuk menghitung recovery proses konsentrasi dengan palong yang telah dilakukan. Palong yang digunakan secara skematik diilustrasikan dalam Gambar 1.

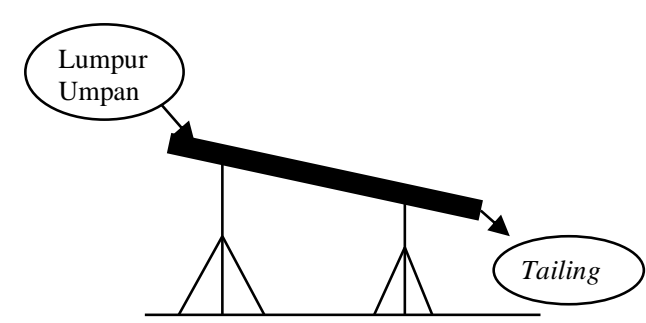

Gambar 1. Skematik palong (tampak samping)

\subsubsection{Proses flotasi}

Proses flotasi dilakukan dalam suatu alat flotasi dengan kapasitas $5 \mathrm{~kg}$ dan kecepatan pengadukan $1425 \mathrm{rpm}$. Proses yang terjadi dalam tahap ini adalah sebanyak 7 liter air, $10 \mathrm{~mL}$ frother (pine oil) dan kolektor (xylene) yang divariasi sebanyak $10 \mathrm{~mL}, 15 \mathrm{~mL}, 20 \mathrm{~mL}, 25 \mathrm{~mL}$ dimasukkan ke dalam alat flotasi. Sebanyak $1 \mathrm{~kg}$ sampel bijih emas yang telah dihaluskan dimasukkan ke dalam alat flotasi. Alat flotasi dihidupkan dan larutan dikondisikan berada di dalamnya selama 10 menit. Selanjutnya dilakukan pengecekan $\mathrm{pH}$ larutan. Apabila $\mathrm{pH}$ larutan terlalu asam, $\mathrm{pH}$ diatur dengan penambahan sodium silikat sebanyak yang dibutuhkan agar $\mathrm{pH}$ sesuai dengan yang diharapkan yaitu $\mathrm{pH}$ 8. Setelah $\mathrm{pH}$ sesuai dengan yang diinginkan lalu flotasi dioperasikan secara keseluruhan selama waktu yang ditentukan yaitu 25 menit, kemudian udara dialirkan melalui kompresor dengan pengaturan laju alir udara. Fenomena yang terjadi diamati selama proses berlangsung. Pada menit ke-4 biasanya konsentrat akan mulai keluar dari atas. Setelah proses berlangsung selama waktu yang ditentukan yaitu 25 menit, alat flotasi dimatikan. Konsentrat dan tailing dikeluarkan kemudian alat flotasi dibersihkan dengan menggunakan air. Hasil flotasi disaring menggunakan penyaring vakum, kemudian hasil penyaringan dipanaskan di dalam oven untuk menghilangkan kadar air. Berat akhir dari hasil flotasi ditimbang dan kadar $\mathrm{Au}$ dan Ag dalam konsentrat dan tailing dianalisis untuk menghitung recovery proses flotasi. Peningkatan konsentrasi emas dengan menggunakan palong dan proses flotasi yang dilakukan dapat dilihat pada Gambar 2. 


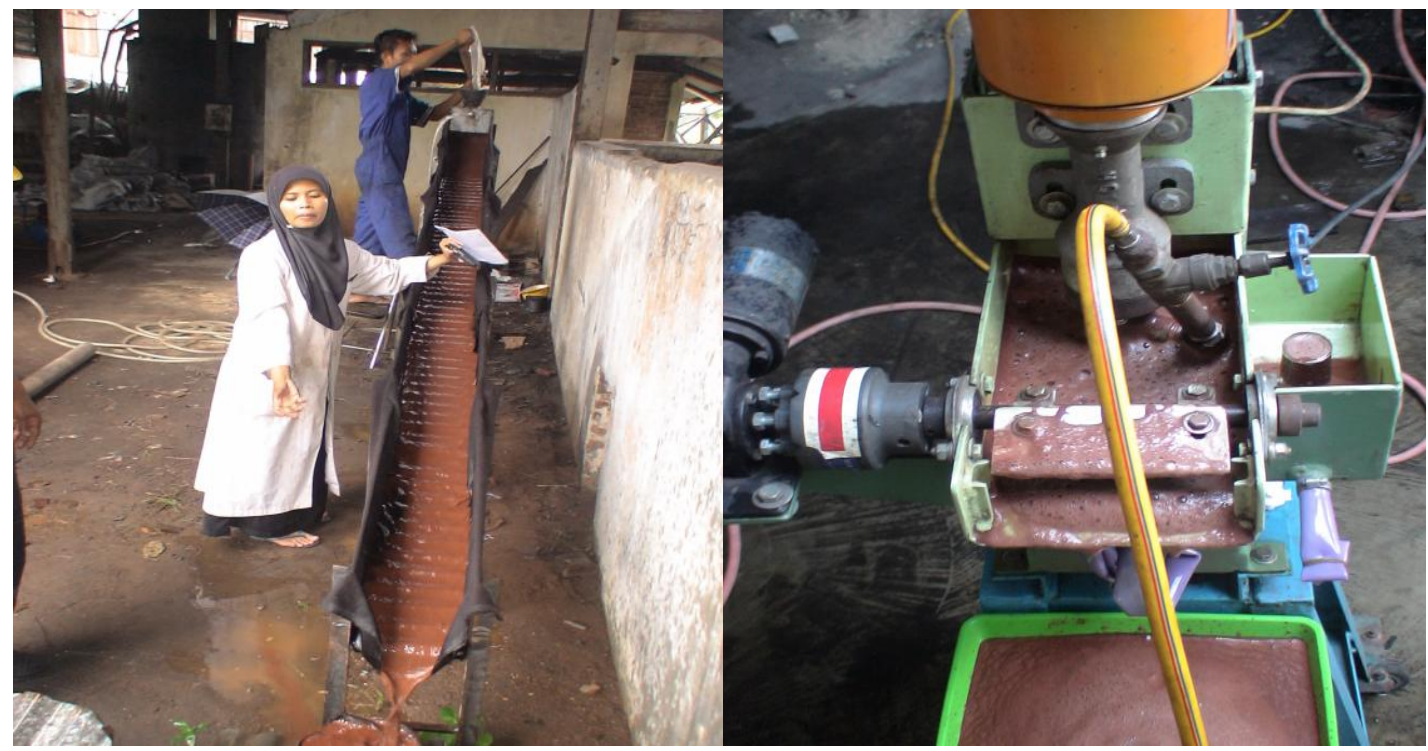

Gambar 2. Proses peningkatan konsentrasi dengan palong dan proses flotasi bijih emas dan perak dari Provinsi Lampung

\section{Hasil dan Pembahasan}

\subsection{Proses Peningkatan Konsentrasi dengan Palong}

Proses benefisiasi menggunakan konsentrasi gravitasi perlu dilakukan terlebih dahulu sebelum dilakukan proses flotasi untuk mengurangi beban alat flotasi dan mengurangi jumlah reagen flotasi yang digunakan. Seperti yang dilakukan oleh Beattie Consulting Ltd. dalam penelitiannya mengenai konsentrasi gravitasi dan flotasi bijih emas dari Spanish Mountain Deposit di British Columbia Kanada, diketahui bahwa proses flotasi yang dilakukan setelah dilakukan konsentrasi gravitasi terlebih dahulu menghasilkan persen recovery emas yang lebih besar dibandingkan dengan proses flotasi tanpa dilakukan konsentrasi gravitasi sebelumnya (Beattie, 2010).

Dari proses konsentrasi dengan palong akan diperoleh konsentrat dan tailing dengan jumlah dan kadar emas dan perak yang tertentu sehingga dapat dihitung persen recovery proses konsentrasi dengan palong yang dilakukan. Recovery emas dan perak dalam proses konsentrasi dengan palong dinyatakan dengan Persamaan (1):

$$
R=\frac{C . c}{F . f} \times 100 \%
$$

dengan

$R=$ recovery, $\%$

$C=$ berat konsentrat, gram

$c=$ kadar $\mathrm{Au}$ atau $\mathrm{Ag}$ dalam konsentrat, gram/ton

$F=$ berat umpan, gram

$F=$ kadar Au atau Ag dalam umpan, gram/ton

Hasil percobaan dan perhitungan recovery dari proses konsentrasi dengan palong bijih emas dan perak disajikan pada Tabel 2.

Tabel 2. Hasil percobaan proses konsentrasi dengan palong bijih emas dan perak

\begin{tabular}{ccccccccc}
\hline \multirow{2}{*}{$\begin{array}{c}\text { Ukuran } \\
(\mathrm{Mesh})\end{array}$} & \multirow{2}{*}{$\begin{array}{c}\text { Berat konsentrat } \\
(\mathrm{g})\end{array}$} & \multicolumn{2}{c}{ Kadar konsentrat } & \multicolumn{2}{c}{ Berat } & \multicolumn{2}{c}{ Kadar tailing } & \multicolumn{2}{c}{ Recovery $(\%)$} \\
\cline { 7 - 9 } & $\mathrm{Au}(\mathrm{g} /$ ton $)$ & $\mathrm{Ag}(\mathrm{g} /$ ton $)$ & tailing $(\mathrm{g})$ & $\mathrm{Au}(\mathrm{g} /$ ton $)$ & $\mathrm{Ag}(\mathrm{g} /$ ton $)$ & $\mathrm{Au}$ & $\mathrm{Ag}$ \\
\hline$-60+80$ & 161,84 & 0,39 & 13,6 & 786,99 & 0,37 & 11,0 & 51,32 & 80,47 \\
$-80+100$ & 157,99 & 0,42 & 13,33 & 779,13 & 0,31 & 10,2 & 70,33 & 91,73 \\
$-100+150$ & 136,77 & 0,42 & 13,8 & 813,23 & 0,29 & 6,3 & 76,52 & 94,83 \\
$-150+200$ & 115,85 & 0,43 & 15,03 & 829,17 & 0,31 & 7,0 & 66,01 & 86,39 \\
-200 & 97,70 & 0,31 & 7,2 & 846,30 & 0,42 & 15,2 & 29,67 & 15,23 \\
\hline
\end{tabular}


Gambar 3 menunjukkan hubungan antara ukuran partikel bahan baku batuan emas terhadap nilai recovery emas dan perak dalam proses konsentrasi dengan palong.

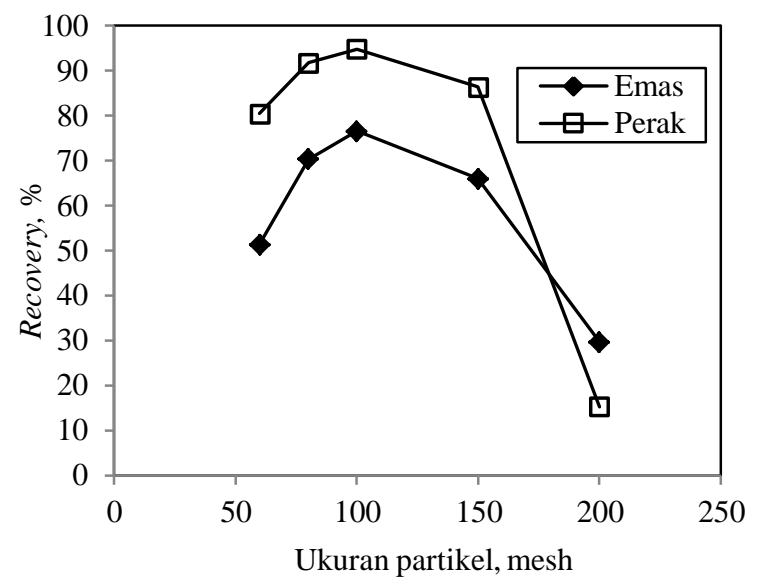

Gambar 3. Pengaruh ukuran partikel terhadap recovery emas dan perak dalam proses konsentrasi dengan palong

Dari Gambar 3 diketahui bahwa nilai recovery emas dan perak optimal untuk proses konsentrasi dengan palong diperoleh pada ukuran partikel bahan baku batuan emas sebesar $-100+150$ mesh yaitu $76,52 \%$ untuk recovery emas dan $94,83 \%$ untuk recovery perak. Hal ini menunjukkan penggunaan ukuran partikel yang tepat dapat memberikan hasil recovery yang baik. Hal ini kemungkinan terjadi karena ukuran partikel yang lebih halus dan yang lebih kasar yang mengandung emas ikut terbawa oleh daya dorong aliran air sehingga mengakibatkan hanya sedikit yang tertahan pada riffle.

\subsection{Proses Flotasi}

\subsubsection{Pengaruh ukuran partikel}

Ukuran partikel bijih merupakan salah satu parameter yang berpengaruh pada proses flotasi. Secara umum dikatakan pada beberapa literatur bahwa aktivitas flotasi akan meningkat dengan semakin kecilnya ukuran partikel bijih. Markovic dan Milosavljevic (2002) menemukan bahwa ukuran partikel terbaik untuk proses flotasi yang diperoleh pada penelitiannya adalah <200 mesh. Pada penelitian ini, akan dipelajari pengaruh ukuran partikel bijih emas terhadap recovery emas pada proses flotasi. Variasi ukuran partikel bijih yang digunakan adalah -60+80 mesh, 80+100 mesh, -100+150 mesh, -150+200 mesh, dan -200 mesh. Variabel proses tetap yang digunakan untuk mempelajari pengaruh ukuran partikel bijih adalah konsentrasi kolektor sebanyak $25 \mathrm{~mL} / \mathrm{kg}$, konsentrasi frother $10 \mathrm{M}$, pH slurry 8, waktu pengkondisian 10 menit dan waktu penggarukan konsentrat 25 menit. Berat sampel konsentrat hasil proses pencucian yang digunakan dalam proses flotasi sebanyak $2,5 \mathrm{~kg}$ dengan kadar Au sebesar 2,9 gram/ton dan kadar Ag sebesar 11 gram/ton. Dari proses flotasi ini diperoleh konsentrat dan tailing dengan jumlah dan kadar $\mathrm{Au}$ serta Ag tertentu sehingga dapat dihitung recovery $\mathrm{Au}$ dan $\mathrm{Ag}$ hasil proses flotasi sesuai dengan Persamaan (1). Hasil percobaan dan perhitungan recovery dari proses flotasi bijih emas dan perak untuk mempelajari pengaruh ukuran partikel disajikan pada Tabel 3.

Tabel 3. Hasil percobaan pengaruh ukuran partikel pada proses flotasi bijih emas dan perak

\begin{tabular}{|c|c|c|c|c|c|c|c|c|}
\hline \multirow{2}{*}{$\begin{array}{l}\text { Ukuran } \\
\text { (Mesh) }\end{array}$} & \multirow{2}{*}{$\begin{array}{l}\text { Berat konsentrat } \\
\text { (gr) }\end{array}$} & \multicolumn{2}{|c|}{ Kadar konsentrat } & \multirow{2}{*}{$\begin{array}{c}\text { Berat Tailing } \\
\text { (gr) }\end{array}$} & \multicolumn{2}{|c|}{ Kadar tailing } & \multicolumn{2}{|c|}{ Recovery (\%) } \\
\hline & & $\mathrm{Au}$ (gr/ton) & $\overline{\mathrm{Ag} \text { (gr/ton) }}$ & & $\mathrm{Au}$ (gr/ton) & $\mathrm{Ag}$ (gr/ton) & $\mathrm{Au}$ & $\mathrm{Ag}$ \\
\hline$-60+80$ & 677,51 & 5 & 55 & 1729,07 & 1,4 & 5,78 & 71,84 & 53,03 \\
\hline$-80+100$ & 705,63 & 26 & 37 & $1.688,20$ & 0,6 & 4,07 & 81,18 & 70,79 \\
\hline$-100+150$ & 781,25 & 33 & 86 & $1.562,50$ & 0,8 & 2,07 & 95,03 & 83,18 \\
\hline$-150+200$ & 833,33 & 92 & 197 & $1.441,67$ & 0,05 & 1,57 & 98,33 & 86,42 \\
\hline-200 & 751,24 & 31 & 51 & $1.448,01$ & 0,47 & 4,34 & 85,08 & 66,18 \\
\hline
\end{tabular}


Gambar 4 menunjukkan hubungan antara ukuran partikel bahan baku batuan emas terhadap recovery emas dan perak pada proses flotasi.

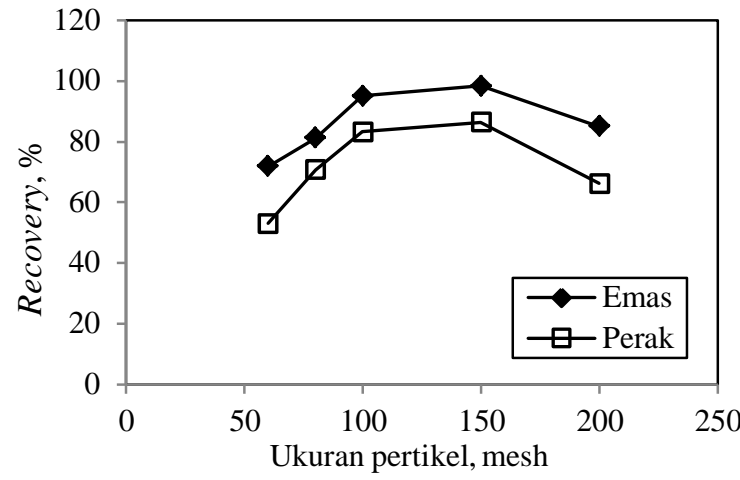

Gambar 4. Pengaruh ukuran partikel terhadap recovery emas dan perak dalam proses flotasi.

Dari Gambar 4 diketahui bahwa nilai recovery yang paling optimal untuk proses flotasi dengan konsentrasi kolektor $25 \mathrm{ml} / \mathrm{kg}$ dan waktu proses 25 menit diperoleh pada ukuran partikel bahan baku batuan emas -150+200 mesh yaitu 98,33\% untuk recovery emas dan $86,42 \%$ untuk recovery perak. Hal ini juga sesuai dengan hasil penelitian yang dilakukan oleh Beattie Consulting Ltd dalam penelitiannya mengenai konsentrasi gravitasi dan flotasi bijih emas dari Spanish Mountain Deposit di British Columbia Kanada, diketahui bahwa persen recovery emas terbaik diperoleh pada ukuran partikel $97 \mu \mathrm{m}$ atau sekitar -140+170 mesh (Beattie, 2010). Hal ini menunjukkan penggunaan ukuran partikel yang tepat dapat memberikan hasil recovery yang baik. Peningkatan ukuran partikel dapat menghasilkan waktu induksi yang lebih lama, cakupan daya tarik hidrofobik yang lebih tinggi pada permukaan partikel akan meningkatkan kestabilan antara gelembung dengan agregat partikel (Subrahmanyam \& Forssberg, 1988; Feng \&Aldrich, 1999). Selain itu kemungkinan fraksi ukuran yang lebih kasar mempunyai kecenderungan yang lebih rendah dalam mekanisme non-selective entrainment (penangkap tidak selektif) (Fuerstenau, 1980; Feng \&Aldrich, 1999), penurunan pemutusan ikatan gelembung dari permukaan partikel kasar serta adsorpsi reagen yang lebih selektif (Fuerstenau, 1980), sehingga pada ukuran partikel yang lebih rendah recovery-nya menurun. Namun dengan ukuran partikel yang terlalu besar, daya ikat antara gelembung dengan agregat partikel tidak cukup kuat untuk mencegah partikel terlepas dari permukaan gelembung karena berat partikel pada saat fase agregat (kumpulan partikel yang menempel) naik ke fase buih (Nguyen, 2003).

\subsubsection{Pengaruh konsentrasi kolektor}

Konsentrasi kolektor merupakan salah satu parameter yang penting dalam proses flotasi. Beberapa literatur menyatakan bahwa peningkatan konsentrasi kolektor memberikan pengaruh yang positif terhadap recovery logam yang diinginkan pada proses flotasi sampai pada konsentrasi tertentu (Petrus dkk., 2012). Pada penelitian ini, setelah diketahui bahwa ukuran partikel bijih yang memberikan persen recovery proses flotasi terbaik yaitu $-150+200$ mesh, selanjutnya dilakukan percobaan untuk mempelajari pengaruh volume kolektor untuk proses flotasi dengan ukuran bijih $-150+200$ mesh. Konsentrasi kolektor yang dipelajari bervariasi yaitu $5-30 \mathrm{~mL} / \mathrm{kg}$. Kondisi proses yang digunakan untuk mempelajari pengaruh konsentrasi kolektor adalah ukuran partikel 100+150 mesh, konsentrasi frother $10 \mathrm{M}, \mathrm{pH}$ slurry 8, waktu pengkondisian 10 menit dan waktu penggarukan konsentrat 25 menit. Berat sampel konsentrat hasil proses pencucian yang digunakan dalam proses flotasi sebanyak $2,5 \mathrm{~kg}$ dengan kadar Au sebesar 2,9 gram/ton dan kadar Ag sebesar 11 gram/ton. Dari proses flotasi ini diperoleh konsentrat dan tailing dengan jumlah dan kadar $\mathrm{Au}$ serta Ag tertentu sehingga dapat dihitung recovery $\mathrm{Au}$ dan $\mathrm{Ag}$ hasil proses flotasi sesuai dengan persamaan (1). Hasil percobaan dan perhitungan recovery dari proses flotasi bijih emas dan perak untuk mempelajari pengaruh konsentrasi kolektor disajikan pada Tabel 4. 
Tabel 4. Hasil percobaan pengaruh konsentrasi kolektor pada proses flotasi bijih emas dan perak

\begin{tabular}{|c|c|c|c|c|c|c|c|c|}
\hline \multirow{2}{*}{$\begin{array}{l}\text { Volume } \\
\text { kolektor } \\
(\mathrm{mL} / \mathrm{kg})\end{array}$} & \multirow{2}{*}{$\begin{array}{c}\text { Berat } \\
\text { konsentrat } \\
(\mathrm{g})\end{array}$} & \multicolumn{2}{|c|}{$\begin{array}{l}\text { Kadar konsentrat } \\
\text { (gr/ton) }\end{array}$} & \multirow{2}{*}{$\begin{array}{l}\text { Berat tailing } \\
(\mathrm{g})\end{array}$} & \multicolumn{2}{|c|}{ Kadar tailing } & \multicolumn{2}{|c|}{$\begin{array}{c}\text { Recovery } \\
(\%)\end{array}$} \\
\hline & & $\mathrm{Au}$ & $\mathrm{Ag}$ & & $\mathrm{Au}$ (g/ton) & $\mathrm{Ag}$ (g/ton) & $\mathrm{Au}$ & $\mathrm{Ag}$ \\
\hline 10 & 786,54 & 11,86 & 57,80 & 1502,98 & 0,67 & 4,06 & 81,50 & 67,86 \\
\hline 15 & 807,86 & 58,07 & 103,98 & $1.446,87$ & 0,42 & 3,06 & 86,14 & 74,37 \\
\hline 20 & 812,98 & 66,00 & 208,09 & $1.439,64$ & 0,36 & 2,78 & 88,07 & 75,74 \\
\hline 25 & 833,33 & 92,00 & 197,00 & $1.441,67$ & 0,05 & 1,57 & 98,33 & 86,42 \\
\hline 30 & 976,51 & 41,87 & 89,96 & $1.298,43$ & 0,40 & 2,96 & 87,04 & 75,58 \\
\hline
\end{tabular}

Gambar 5 menunjukkan hubungan antara konsentrasi kolektor (xylene) terhadap nilai recovery emas dan perak dalam proses flotasi.

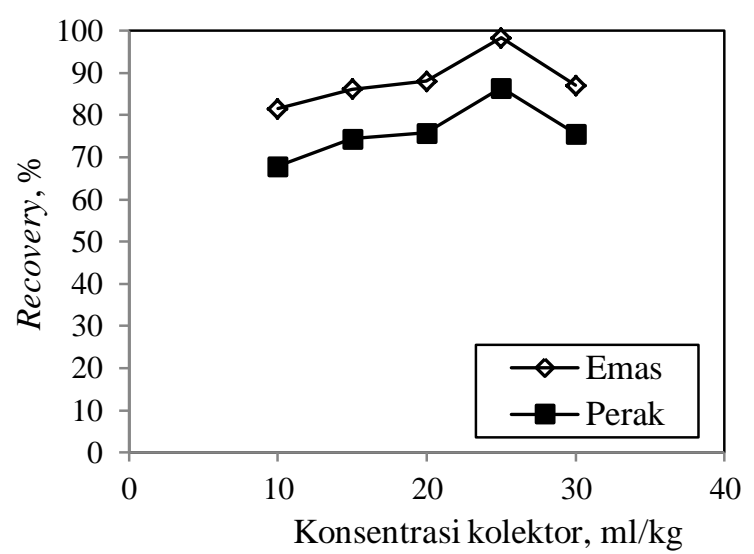

Gambar 5. Pengaruh konsentrasi kolektor terhadap recovery emas dan perak dalam proses flotasi

Gambar 5 menunjukkan bahwa nilai recovery paling optimal untuk proses flotasi pada waktu proses 25 menit dan ukuran partikel bahan baku -150+200 mesh diperoleh pada konsentrasi kolektor $25 \mathrm{ml} / \mathrm{kg}$ yaitu $98,33 \%$ untuk recovery emas dan $86,42 \%$ untuk recovery perak. Pada volume kolektor $<25 \mathrm{~mL} / \mathrm{kg}$, kemampuan kolektor mengumpulkan kandungan emas dan perak belum maksimal, sedangkan pada volume kolektor $>25 \mathrm{ml} / \mathrm{kg}$, kandungan emas dan perak yang terkumpul oleh kolektor sudah maksimal dan jenuh sehingga nilai recovery menurun. Peningkatan konsentrasi kolektor yang diikuti oleh kenaikan persen recovery menunjukkan terjadinya peningkatan sudut kontak secara signifikan sehingga gelembung melekat dengan baik kepermukaan partikel. Namun apabila jumlah kolektornya berlebih, maka partikel yang seharusnya hidrofilik berubah sifatnya dan ikut melekat ke gelembung, sehingga menurunkan recovery.

\subsubsection{Pengaruh waktu penggarukan}

Percobaan flotasi juga dilakukan dengan variabel waktu penggarukan yang berbeda-beda yaitu 15, 25, 45, dan 75 menit. Kondisi proses yang digunakan untuk mempelajari pengaruh waktu penggarukan adalah ukuran partikel 100+150 mesh, konsentrasi frother $10 \mathrm{M}$, konsentrasi kolektor $25 \mathrm{~mL} / \mathrm{kg}$, pH slurry 8 dan waktu pengkondisian 10 menit. Berat sampel konsentrat hasil proses pencucian yang digunakan dalam proses flotasi sebanyak $2,5 \mathrm{~kg}$ dengan kadar Au sebesar 2,9 gram/ton dan kadar Ag sebesar 11 gram/ton. Dari proses flotasi ini diperoleh konsentrat dan tailing dengan jumlah dan kadar Au serta Ag tertentu sehingga dapat dihitung recovery $\mathrm{Au}$ dan $\mathrm{Ag}$ hasil proses flotasi sesuai dengan Persamaan (1). Hasil percobaan dan perhitungan recovery dari proses flotasi bijih emas dan perak untuk mempelajari pengaruh waktu penggarukan disajikan pada Tabel 5.

Tabel 5. Hasil percobaan pengaruh waktu penggarukan pada proses flotasi bijih emas dan perak

\begin{tabular}{|c|c|c|c|c|c|c|c|c|}
\hline \multirow{2}{*}{$\begin{array}{l}\text { Waktu penggarukan } \\
\text { (menit) }\end{array}$} & \multirow{2}{*}{$\begin{array}{c}\text { Berat } \\
\text { konsentrat }(\mathrm{g})\end{array}$} & \multicolumn{2}{|c|}{ Kadar konsentrat } & \multirow{2}{*}{$\begin{array}{l}\text { Berat tailing } \\
\quad(\mathrm{g})\end{array}$} & \multicolumn{2}{|c|}{ Kadar tailing } & \multicolumn{2}{|c|}{ Recovery $(\%)$} \\
\hline & & $\mathrm{Au}$ (g/ton) & $\mathrm{Ag}$ (g/ton) & & $\mathrm{Au}(\mathrm{g} / \mathrm{ton})$ & $\mathrm{Ag}$ (g/ton) & $\mathrm{Au}$ & $\mathrm{Ag}$ \\
\hline 15 & 704,23 & 63 & 281 & 1654,93 & 0,25 & 1,7 & 91,74 & 85,06 \\
\hline 25 & 833,33 & 92 & 197 & $1.441,67$ & 0,05 & 1,57 & 98,33 & 86,42 \\
\hline 45 & 896,06 & 57 & 101 & $1.469,53$ & 1,40 & 2,01 & 89,47 & 83,39 \\
\hline 75 & 868,06 & 14,7 & 33,65 & 1501,74 & 1,01 & 4,08 & 69,98 & 71,59 \\
\hline
\end{tabular}


Gambar 6 menunjukkan hubungan waktu proses terhadap nilai recovery emas dan perak dalam proses flotasi.

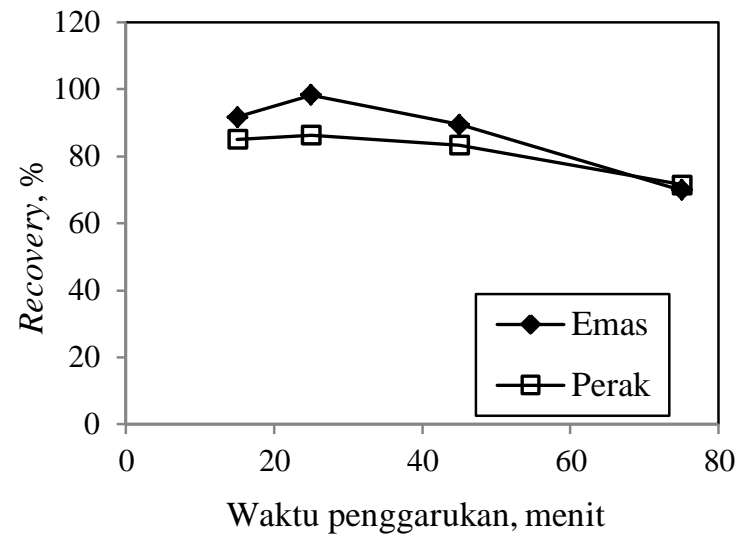

Gambar 6. Pengaruh waktu penggarukan terhadap recovery emas dan perak dalam proses flotasi.

Nilai recovery paling optimal untuk proses flotasi dengan konsentrasi kolektor $25 \mathrm{~mL} / \mathrm{kg}$ dan ukuran partikel $-150+200$ mesh diperoleh pada waktu proses 25 menit yaitu $98,33 \%$ untuk recovery emas dan $86,42 \%$ untuk recovery perak seperti ditunjukkan pada Gambar 6. Penurunan persen recovery pada waktu yang lebih lama kemungkinan disebabkan karena dalam larutan kondisi $\mathrm{pH}$ telah berubah, konsentrasi kolektor dan frother yang telah berkurang. Hal ini menyebabkan daya ikat gelembung menjadi lemah dan mudah pecah sehingga partikel tidak terangkat dengan baik.

\section{Kesimpulan}

Kesimpulan yang dapat diambil dari penelitian ini adalah

1. Kondisi operasi paling optimal yang digunakan untuk proses flotasi emas dan perak dari bahan baku batuan emas yang berasal dari Provinsi Lampung adalah ukuran partikel bahan baku $-150+200$ mesh, konsentrasi kolektor $25 \mathrm{~mL} / \mathrm{kg}$, dan waktu proses 25 menit dengan nilai recovery sebesar 98,33\% untuk emas dan $86,42 \%$ untuk perak.

2. Perlu dilakukan proses pencucian terlebih dahulu sebelum dilakukan proses flotasi dengan ukuran partikel bahan baku terbaik adalah $-100+150$ mesh.
3. Kandungan konsentrat emas terbaik yang dapat diperoleh adalah 92 ppm dan kandungan konsentrat perak terbaik adalah $281 \mathrm{ppm}$.

4. Frother yang digunakan adalah pine oil dankolektor yang digunakan adalah xylene.

\section{Daftar Pustaka}

Beattie M.J.V., 2010, Gravity Concentration and Flotation of Spanish Mountain Composites, A Summary Report from Beattie Consulting Ltd, Canada.

Feng, D., Aldrich, C., 1999, Effect of particle size on flotation performance of complex sulphide ores, Minerals Engineering, 7, 721-731.

Ferdana, A.D., Petrus, H.T.B.M,Bendiyasa, I.M., Prijambada, I.D., Hamada, F. and Sachiko, F., 2018, Optimization of gold ore Sumbawa separation using gravity method: Shaking table, AIP Conference Proceedings 1945, 020070; doi: 10.1063/1.5030292.

Fuerstenau, D.W., 1980, Fine particle flotation", in: P. Somasundaram, (Ed.), Fine Particles Process., pp. 669-705.

Kementerian ESDM, 2017, Laporan Kinerja Kementerian ESDM 2017, Kementerian Energi dan Sumber Daya Mineral, Jakarta.

Markovic, Z. S., and Milosavljevic, S., 2010, Effect of the particle size and mineralogy on flotation recovery at copper ore flotation, Proceeding of the V International Conference in Metallurgy, Refractories and Environment, 223-229.

Marsden, J and House, I, 1999, The Chemistry of Gold Extraction, Ellis Horwood, New York.

Nguyen, A.V., 2003, New method and equations for determining attachment tenacity and particle size limit in flotation, Int. J. Miner. Process., 68, 167-182.

Petrus, H.T.B.M., Hirajima, T., Sasaki, K., Okamoto, H., 2012, Effects of sodium thiosulphate on chalcopyrite and tennantite: An insight for alternative separation technique, Int. J. Miner. Process., 102-103, 116-123

Prasetya, A., Mawadati, A., Putri, A.M.R., and Petrus, H.T.B.M, 2018, Study on Sumbawa gold ore liberation using rod mill: effect of 
rod-number and rotational speed on particle size distribution, IOP Conf. Series: Mat. Sci. Eng., 285, 012024

Sudarsono, A.S., 2003, Pengantar Pengolahan dan Ekstraksi Bijih Emas, Departemen Teknik Pertambangan, Institut Teknologi Bandung, Bandung

Subrahmanyam, T.V., Forssberg, E., 1988,Froth stability, particle entrainment and drainage in flotation-A review, Int. J. Miner. Process., 23, 33-53.

Wahyudi, T., 2004, Penambangan dan Pengolahan Emas di Indonesia, PuslitbangTeknologi Mineral dan Batubara, Badan Litbang Energi dan Sumber Daya Mineral, Jakarta

Walkin, C. J., 2009, Sluice Boxing 101, http://ezinearticles.com/?Sluice-Boxing101\&id=2598916, diakses pada tanggal 22 Juni 2018. 